\title{
Yazım Kuralları Öğretiminde Duvar Yazılarından Yararlanma
}

\section{Use of Graffiti in Teaching of Writing Rules}

\author{
Rezan Karakaş, ${ }^{\mathrm{a},{ }^{*}}$ Erhan Akın ${ }^{\mathrm{b}}$ \\ ${ }^{a}$ Doç. Dr., Siirt Üniversitesi, Eğitim Fakültesi, Sosyal Bilimler ve Türkçe Eğitimi Bölüm, 56100, Siirt/Türkiye. \\ ORCID: 0000-0001-9138-3825 \\ ${ }^{\text {b }}$ Dr. Öğr. Üyesi, Siirt Üniversitesi, Eğitim Fakültesi, Sosyal Bilimler ve Türkçe Eğitimi Bölüm, 56100, Siirt/Türkiye. \\ ORCID: 0000-0003-2372-9331
}

\section{MAKALE BILLGİSI}

\section{Makale Geçmişi:}

Başvuru tarihi: 16 Ocak 2018

Düzeltme tarihi: 22 Şubat 2018

Kabul tarihi: 06 Mart 2018

\section{Anahtar Kelimeler: \\ Yazma Eğitimi \\ Yazım Kuralları \\ Duvar Yazıları \\ Görsel Materyal}

\section{ARTICLE INFO}

\section{Article history:}

Received 16 January 2018

Received in revised form 22 February 2018

Accepted 06 March 2018

\section{Keywords:}

Writing Education

The Rules of Writing

Graffiti

Visual Material

\section{ÖZ}

Yazma eğimi, diğer temel dil becerileri ile ilişkili ve çok yönlü bir süreçtir. Yazım kuralları konusu ise yazma eğitimi sürecindeki önemli unsurlardan biridir. Bir yazıda kullanılan dilin yazım kurallarına uygunluğu, yazının bütünlüğü ve estetiği açısından önem taşır. Bu araştırmada eğitim sürecinin hemen her basamağında ve sonraki dönemlerde bireylerin sıklıkla yaşadığı problemlerden biri olan yazım yanlışlıkları üzerinde durulmuștur. Büyük/küçük harflerin, birleșik kelimelerin, $k i$ ve $d e$ bağlaçlarının, eklerin yazımında yapılan yanlışlıklar, yazının gerek içeriğini gerekse biçimsel yönünü olumsuz yönde etkilemektedir. Bu makalede duvar yazılarının imla hatalarının önlenmesine yönelik katkı sunacağı düşüncesinden yola çıkılarak niteliksel bir çalışma yapılmıştır. Çalışmada duvar yazılarının eğitim-öğretim sürecinin hemen her basamağında, bilhassa ortaokul ve lise döneminde yazım kurallarının öğretilmesi amacıyla kullanılabileceğine vurgu yapılmaktadır.

\section{A B S TR ACT}

Writing education is a multifaceted process that is associated with reading, listening and observation skills. The rules of writing, on the other hand, is one of the componets of the writing education. The language used in a writing is of great importance for the integrity and esthetics of a writing. In this study, writing mistakes that individuals make during or after their education will be examined. The mistakes done in writing the capital and small letters, compund words and conjuctions have a negative impact on both the content and style of a writing. In this article, the role of grafiti in the avoidance of the spelling errors has been analysed qualitatively. It has been concluded that grafitti can be used for teaching of the writing rules during education process, particulary during the education at secondary and high school.

\section{Giriş}

Yazma; duygu, düşünce, olay ve hayallerin önceden öğrenilmiş semboller sistemiyle çoğunlukla okuyuculara veya dinleyicilere yönelik olarak aktarılmasıdır. Yazının varlığı için her durumda bir okuyucu veya dinleyici kitlesine ihtiyaç yoktur. Bunlar olmadan da yazı varlığını sürdürür. Yazı, muhatabının eline ulaştığında ise yazar ile okuyucu/dinleyici arasında bir iletişim ağı kurulmuş olur.

* Sorumlu yazar/Corresponding author.

e-posta: rezankarakas@hotmail.com
Yazma eylemi, bilinen herhangi bir dilin kullandığ ${ }_{1}$ alfabe ile gerçekleştirilir. $\mathrm{Bu}$, yazının şekilsel yönünü oluşturur. Yazının bir başkası tarafından anlaşılırlığı, okuyucunun mevcut alfabeyi bilmesine bağlıdır. Aksi halde yazılan yazı, anlamsız semboller yığını olarak okuyucunun karşısında durur.

Duygu ve düşüncelerin belli bir plan dahilinde bir bütünlük arz edecek şekilde sözlü veya yazılı olarak anlatılması (Korkmaz vd., 2001) manasına gelen kompozisyon kelimesi, Türkçe ve Türk Dili ve Edebiyatı derslerinde sözlü ve yazılı 
anlatımın her ikisini kapsayacak şekilde kullanılmıștır. Yazı yazarken konunun ile ilgili bilgilerin toplanması bu bilgilerin belli bir düzene konulması ve son olarak yazıya şekil verilmesine genel olarak anlatış denilmektedir. Başarılı bir yazıda birlik, denge ve canlılık gibi unsurların da olması gerekmektedir. Çünkü yazar; birlik unsuru ile ana fikirden ayrılmamaya; denge unsuru ile yardımc fikirlerin orantılı bir biçimde sunulmasına ve son olarak canlılık unsuru ile de anlatımın sürükleyici, ilgi uyandırıcı olmasına zemin hazırlar. (Korkmaz vd., 2001). Yazma becerisi kişilerin iletişimdeki önemli kanallarından biridir. Çünkü yazma becerisi kişilerin toplumsallaşmasının da bir sonucudur. $\mathrm{Bu}$ sonuç insanın toplumun bir ferdi olması ile başlar ve iletişimle sürer. Çünkü insanın toplum içindeki dinamik iletişimden uzak durması zordur. $\mathrm{Bu}$ zorunluluk insanı, anlatma gücünü artırma yollarını aramaya mecbur kılar (Özbay, 2013a).

Yazma sürecindeki eksiklik ve başarısızlık konusu, Türkçe eğitiminin ciddi sorunlarından birini oluşturur ve eğitimin hemen her basamağında karşımıza çıkar. Yazma, dinleme ve okuma becerisiyle ilişskili bir aktivitedir. Dinleme ve okuma becerisi kazanmış bir bireyin yazmada da başarılı olacağı beklenir. Okuma, uzun süreli bellekte saklı olan bilgi ve birikimleri fosilleşmekten kurtarır ve canlı tutar. Bu canlılık, yazma sürecinde kişinin ihtiyaç duyduğu birikimi sağlayacak ana kaynak olacaktır. Dinleme de okumadakine benzer bir etki yaratır. Bu durum, havasız kalmış bir odanın havalandırılmasina benzetilebilir. Okumasinı ve dinlemesini bilen birey, belleğindeki bilgi birikimlerini tozlardan arındırarak tazeleme imkânı bulur. Yazmak, neyin nasıl yazılacağıyla ilgilidir. Bu iki soruya yeterli cevabı olmayan kişi, elbette yazı yazarken sıkılacak, dolayısıyla üstü başı dağınık bir adama benzer bir yazı ortaya çıkaracaktır.

“Öğrenciler, uygulamaların tartışılması gerektiğine vurgu yapan bilişsel çıraklık eğitimi programları aracılı̆̆ıla yazma yeteneklerini geliştirebilirler. Bireyin üst düzeyde yazma yeteneği kazanmasl ve uygulamayla ilgili dikkatin çok yönlü yazma sürecini başarll bir şekilde koordine edebilmesi, sistematik bir ĕgitimle mümkündür" (Kellogg, 2008). Pulitzer Ödüllü Amerikalı yazar, Norman Mailer ${ }^{1}$, yazma konusunda şunları söyler: "Ben yazmayı yazarak ögrendim. Şöyle bir hesap yaptı̆̆ımda Naked and Dead'i yazmadan önce bir milyon kelimenin yarısından daha fazla kelime yazmış olmalıyım" (Kellogg, 2008: 17). Yazma eğitimindeki başarının anahtarı, bu konuda alınacak sistemli bir eğitim ve uygulamanın sık olduğu ortamlarda saklıdır. Ne kadar çok yazılır ve tekrar yapılırsa yazıma dair kusurlar, bir o kadar azalır veya ortadan kalkar. Yazma sürecinde etkili olan tüm unsurlar, kişinin sahip olduğu bilgi ve bu bilginin metne aktarılması, arkasından metin taslağının içerik ve biçim yönünden gözden geçirilmesi, kişinin bu konuya dair aldığı eğitimsel birikimle doğrudan ilişkilidir. Bunların her biri birbirlerini tamamlayıcı işleve sahiptir.

Carter (2002: 5) çalışmasında, yazma sürecinin bütünlük arz etmesinden bahseder ve kısaca yazma süreci ile ilgili olarak şu hususlara değinir: Öncelikle konunun öğrencilere uygun olmasına dikkat etme, sonrasında konu ile ilgili öğrencileri bilgilendirme, gerekirse onlara örnek metin sunma ve yeni metinler oluşturma, bunu değerlendirme, paylaşma ve son okumayı yaparak metne son şekli vermektedir. Bütün bunlar dikkate alındığında yazma sürecinin meşakkatli, ancak bir o kadar da zevkli bir uğraş olduğuna kanaat getirilebilir.
Raimes (1983), yazma sürecinin genellikle bireysel bir aktivite olarak görüldüğünü, ancak her durum için böyle olmak zorunda olmadığını söyleyerek, yazma dersi planlanırken öğrencilerin yazmadan önce, yazarken ve yazdıktan sonra birbirleriyle etkileşim halinde olabileceklerine vurgu yapar. Raimes (1983), yazma eğitimiyle ilgili bazı tespitlerde de bulunur: Yazma eğitiminde resim, fotoğraf, poster, karikatür, slayt, magazin reklamları, harita, çizelge ve grafik gibi görsellerin kullanımının önemli derecede yararlı olacağını dile getirerek şunları söyler: Kişisel bir deneyim ile ilgili bir yazım söz konusu olduğunda öğrenciler arasında bir paylaşım olmaz. Oysaki sınıfta gösterilen bir resim hakkında öğrencilerin çeşitli deneyimlerini paylaşmaları mümkündür. $\mathrm{Bu}$ sayede çeşitli dil aktiviteleri ortaya çıkmakta, öğrenciler, gördükleri resme dair gözlemlerini çeşitli kelime, deyim ve cümlelerle anlatma yoluna gitmektedirler.

Yazma becerisi (Demir A., 2014: 21), kişinin eleştirel düşünme ve problem çözme becerisini geliştirir, bireyi araştırmaya, eksikliklerini tamamlamaya, yanlışlarını düzeltmeye yönlendirir. Yazma yeteneği, kişinin zihince olgunlaşmasına yardım eder, aynı zamanda akademik başarısında da söz sahibidir. Bütün bu sebeplerden yazma becerisi eğitimde önemli bir yer tutar.

Yazma becerisinin kişinin okul dönemi ve sonrası yaşantısında önemli bir yere sahip olması sebebiyledir ki yazı dilinin kullanılmaya başlandığı ilkokul 1. sınıftan formal eğitimin sonlandığı yere kadar, yazı dilinin içerik ve biçim yönünden geliştirilmesine çalışılır. Okuma, dinleme, konuşma ve yazma eğitimleri sayesinde dile canlılık, esneklik ve işlevsellik kazandırılır.

Yazma eğitiminde bu esneklik ve işlevsellik yazı ve yazım kuralları ile sağlanabilir. Çünkü duygunun veya düşüncenin yazıya aktarılması, söze aktarılmasından daha zordur. Kelimelerin seçimi ve cümle içindeki yerleri, yazımları ve arkasından noktama imleriyle tamamlanmaları, bu zorluğun bir kısmını oluşturur. Yazılı bir metnin başarısını belirleyen birçok unsur vardır. Paragraf bütünlüğü, özgünlük, akıcılık, etkileyicilik vb. Yazım kurallarına uygunluk ise bu unsurlardan biridir ve metni tamamlayıcı bir etkiye sahiptir. Yazım kuralları, yazıya ait bir dış yapı unsuru gibi görülse de aslında yazım sürecinin daima içindedir. Anlamı etkiler, onu değiştirir, kırar veya düzeltir. Bir yazının içerik yönünden başarısı ile yazım kuralları arasındaki başarısı arasında paralellik vardır. Genel olarak içerik yönünden başarılı olan bir yazıda, yazım kusurlarının da yok denecek kadar az olması beklenir. Çünkü bir dili belli kurallara göre yazmak ve o dildeki kelimeleri yazıda göstermek dile verilen önemin göstergesidir. Yazım kurallarını öğretmede önemli olan husus; öğrencilere düzeylerine uygun bir biçimde ana dilindeki sesleri ve yazım kurallarını kavratmak (Özbay, 2013b), yazıda doğabilecek karışıklıkların önüne geçmek, yanlış okumayı önlemek, okumayı ve anlamayı kolaylaştırmaktır. Bunun sonucunda herkes aynı standartlara göre yazıp okuyacak ve belli kurallara uyacaktır (Sezer ve Erdost, 2011). Nitekim yazım kuralları ve noktalama işaretleri yazı yazma tekniğinin temel unsurlarındandır. Bir yazılı metin, ne kadar başarılı bir içeriğe sahip ise de yazım kurallarına ve noktalama işaretlerine özen gösterilmemişse, yazım tekniği açısından olumsuz bir izlenim yaratır. Çünkü bütün yazı türlerinin bir estetiği sahip olması gerekir (Uludağ, 2002). Bir yazılı metnin yazım kurallarına 
uygunluğu, o metinden alınacak estetik hazzı arttırır. Yazım ve noktalama kuralları, metnin dış süsü gibidir. Metnin ilk görünen kısmı, yani dış kabuğu metnin yazım şeklidir. O, yazıldığı dilin yazım kuralları ve noktalama işaretlerinin kullanımı ile kendini göstermektedir. Çünkü yazım yanlışı barındıran cümlelerde, metinlerde anlam konusunda bozulmaların olması kaçınılmazdır (Bağc1, 2011). Bu durum, cümleyi bozduğu gibi genel olarak metnin de havasını bozar ve okuyucunun zihninde bulanıklık yaratır. Bir yazılı metnin yazım kuralları açısından doğru yazılmasını sağlamak için yazma eğitimi çalışmalarında tashih (redaksiyon) sürecine riayet edilir. Bu aşamada, yazı biçimsel olarak değerlendirilir. Bu biçimsel değerlendirmede önemli unsurlardan birisi de yazım kılavuzu kullanmanın alışkanlık haline getirilmesi hususudur (Coşkun, 2007). Buna dikkat edildiğinde yazıda meydana gelebilecek birçok kusurun önüne geçilmiş olur. Buna uyulmadığında yazıda birçok kusur olacak ve yazının anlamsal bütünlüğünü ve özellikle de estetiğini bozacaktır.

Kusurlu bir yazıyı, kişinin bedenine geniş veya dar gelen bir kıyafete benzetmek mümkündür. Bir kıyafet ne kadar şık olursa olsun, kişinin vücut yapısına uygun değilse, giyen kişiye yakışmaz. Bir yazı içeriği ne kadar başarılı olursa olsun güzel bir dış kabuğa ihtiyaç duyar. Dış kabuktaki renksizlikler ve şekil bozuklukları, içeriğe olan ilgiyi azaltır ve ondaki etkileyicilik unsurlarına zarar verir. Yazılı bir metin, hacmi ne olursa olsun, yazıldığı dilin kurallarına uygunluğu ölçüsünde değer kazanır. Kurallara uygun bir yazım, metnin anlamsal bütünlüğünü tamamlar. Aksi ise metnin zihinde algılanış sürecine zarar verir. $\mathrm{Bu}$ süreç içerisinde ise okuyucunun zihni bulanıklaşır ve anlamsal içerik zedelenir.

Yazım kuralları, eğitimin her basamağında işlenen bir konudur. Ancak öğrencilerin üniversiteye geldikleri zaman dahi yazım konusunda tam bir donanıma sahip olamadıkları görülür. Peki, bu eksiklik neden kaynaklanmaktadır? Öğrenci mi, öğretmen mi? Yoksa öğretim yöntemi veya tekniği mi? Burada her üçünden biri, birkaçı veya tamamı, bu konudaki eksikliğin müsebbibi olabilir. Bu araştırmada yazım konusundaki eksikliklerin öğretim yöntem ve tekniklerle ilgili olabileceği düşünülmekte ve bu durumun daha çok görsel destekli uygulamalar aracılığıyla giderilebileceğine vurgu yapılmaktadır. Duvar yazıları çoğunlukla gençler tarafindan yazılmaktadır. Gençlerin duygu, düşünce ve hayallerinin kısa cümlelerle ifade edildiği bu yazılar, aynı yaş grubundaki diğer öğrencilerin de ilgisini çekecektir. Metin içeriğine olan ilgi sayesinde metinde yer alan herhangi bir yanlış yazım örneği de dikkati çekecek ve bu sayede öğretmen, konu ile ilgili bilgileri sınıf içi diyaloglar ve tartışmalar sayesinde irdeleme imkânı bulacak ve duvar yazıları bu şekilde yazma eğitimi sürecine dâhil edilmiş olacaktır.

Görsel araçlar desteği ile yapılacak yazma eğitimi ve yazım kurallarına yönelik öğretmenlerin kullanılabileceği duvar yazıları ile ilgili süreci şu şekilde sıralayabiliriz:

Duvar yazılarından hareket ederek yapılacak yazma eğitiminde öğretmenler ilk olarak işleyecekleri konu ve hazırlayacakları materyallerin Türkçe öğretim programına uygun olup olmadığına dikkat etmelidir. Öğretmenler daha sonra Türkçe ders kitaplarındaki etkinliklerini de işe katarak hazırlayacakları materyalleri bu etkinliklere destek olarak kullanmalıdır.

Yazma eğitimi konusuna uygun olan duvar yazıları seçilmeli ve bu yazılar hakkında öğrencilere açıklayıcı bilgiler verilmelidir. Böylece öğrenciler, duvar yazıları hakkında fikir sahibi olur. Seçilen duvar yazıları gerekli görüldüğü takdirde sözsüz müziklerle desteklenerek dijital ortama aktarılabilir. Böylece işlenen konuya yönelik görsel materyal hazırlanır ve bu materyaller müzikle desteklenerek öğrencilerin dikkati çekilir. Böylece yazım hataları vb. konularda öğrencilerin eğlenerek öğrenmelerine yönelik bir ortam oluşturulur.

Yazma eğitimine yönelik hazırlanan bu öğrenme ortamı uygulama süreci için projeksiyon cihazı, akıllı tahta, bilgisayar gibi araçlar kullanılabilir. $\mathrm{Bu}$ şekilde öğrenciler için öğrenme ortamı hazırlanmış olur. Tamamlanan bu süreç şu şekilde uygulamaya konulabilir:

1. Duvar yazıları kullanılarak hazırlanan görsel destekli öğrenme ortamında ilk iş Türkçe dersi öğretim programının hedef kitle için belirlediği yazma becerisi kazanımlarının dikkate alınmasıdır.

2. Duvar yazıları kullanılarak hazırlanan görsel destekli öğrenme ortamında öğretmenlerin yapacağı ikinci iş ise hedef kitlenin dikkatini çeşitli yollarla derse çekmektir. Bu görsel ve işitsel araçlarla yapılacağ ilgili öğrencilere yönelik hazırlık soruları yoluyla da yapılabilir. Ayrıca duvar yazıları hakkında bilgi verildikten sonra öğrencilere serbest konulu bir duvar yazısı yazma çalışması yaptırılabilir. Daha sonra işlenecek konuya yönelik olarak hazırlanan duvar yazıları tahtaya yansitılarak derse geçilebilir. Öğrencilerden duvar yazıları ile ilgili konuşmaları istenebilir.

3. Duvar yazıları kullanılarak hazırlanan görsel destekli öğrenme ortamında öğretmenlerin yapacağı üçüncü iş ise duvar yazılarının dersin işlenmesinde aktif olarak kullanılmasıdır. Hazırlanan duvar yazılarındaki duygulara uygun müzik seçimi ile ilgili öğrenciler konuşturularak derse güdülenmeleri sağlanabilir. Öğrenciler derse güdülendikten sonra hazırlanan etkinlikler öğrencilere sunulmalıdır. Duvar yazılarındaki hataların öncelikle öğrenciler tarafından tespit edilmesi sağlanmalıdır. Bu şekilde hatayı bulan öğrenciler doğruya daha rahat ulaşabilir. Öğrencilerin yazım hatalarını müzik eşliğinde eğlenerek bulmaları, ders ortamını adeta bir oyun ortamına dönüștürerek bilginin oyun yoluyla öğrenilmesine vesile olur.

Daha sonra öğrenciler buldukları yazım yanlışlarının düzeltilmiş hâliyle kendi duvar yazılarını oluşturmaya yönlendirilmelidir. Böylece öğrenci kendi duvar yazısını oluşturduğunda aslında yazım yanlışını da öğrenmiş olacak ve doğrusunu kullanacaktır.

4. Duvar yazıları kullanılarak hazırlanan görsel destekli öğrenme ortamında öğretmenlerin yapacağı dördüncü iş ise değerlendirme işlemidir. Öğretici tarafindan öğrencilerin ders işleme esnasında hazırladıkları duvar yazıları sınıfça değerlendirmeye tabi tutulmalı ve varsa yanlıș kullanımlar hemen düzeltilmelidir. Böylece hem yazım yanlışı yapan öğrenciler tespit edilip onlara yönelik yeni çalışmalar yapılmaya başlanmış olur hem de konu tekrar edilmiş olur. Son olarak öğretmenler tarafindan öğrencilere duvar 
yazılarında gördükleri yazım hatalarını tespit etmeye yönelik araştırma ödevi verilebilir. Böylece öğrencinin yazım yanlışlarına yönelik dikkati hep üst düzeyde tutulmuş olur ve bu dikkat zamanla alışkanlığ 1 dönüşebilir.

\section{Yöntem}

Bu araştırma 15 Kasım 2016 ve 19 Haziran 2017 tarihleri arasında Türkiye'de Siirt il merkezinde tespit edilen duvar yazıları dikkate alınarak yapılmıştır. Bu kapsamda tespit edilen duvar yazılarının fotoğrafları çekilmiş, böylelikle 342 adet fotoğraf elde edilmiştir. Bu fotoğraflar, nitel araştırma yöntemlerinden doküman incelemesi ekseninde yorumlanmıştır. Bu yolla araştırılması hedeflenen olgu veya olgular ile ilgili bilgi içeren yazılı ve dijital materyaller incelenmekte ve analiz edilmektedir. Çünkü dokümanlar, nitel araştırmalarda etkili bir şekilde kullanılabilen kaynaklarıdır. $\mathrm{Bu}$ yolla araştırmacı ihtiyacı olan veriyi gözlem veya görüşme yapmaya gerek kalmadan elde eder (Yıldırım ve Şimşek, 2011). Duvar yazıları, yazılı anlatımın bir biçimi olmaları ve üzerlerinde yazıma dair doğru/yanlış ifadeler taşımaları nedeniyle bu araştırmada önemli bir doküman olarak görülmekte ve doküman incelemesi tekniğiyle yazma eğitimi çerçevesinde tahlil edilmektedir.

\section{Bulgular}

\subsection{Yazım Kuralları ve Duvar Yazıları}

TDK Yazım Kılavuzu'nda (2012) yazımla ilgili kurallar 1. Sesler ve Ses Uyumları, 2. Bazı Kelime ve Eklerin Yazılışı, 3. Sayıların Yazılışı, 4. Büyük Harflerin Kullanıldığı Yerler, 5. Birleşik Kelimelerin Yazılıșı, 6. Alıntı Kelimelerin Yazılışı, 7. Yabancı Özel Adların Yazılışı ana başlıklarıyla anlatilır.

\subsubsection{Ki Bağlact ve Ki Eki}

"Ki" bağlacı, kendisinden önce gelen kelimeden ayrı yazılır. Ancak bazı örnekler istisnadır ve bu örneklerde "ki" bağlacı, kendisinden önce gelen kelimeyle kaynaşmış ve birleşmiştir. "Hâlbuki oysaki, mademki, meğerki, illaki, sanki belki, çünkü" kelimeleri buna örnektir. "Ki" yazım bilgisi anlatılırken istisnai durum gösteren bu kelimelerin de öğretilmesi gerekmektedir.

Bağlaç olan "ki" yukarıda belirtilen örnekler dışında kendisinden önce gelen kelimeden ayrı yazılır. Ancak duvar yazısı yazarlarının bu konuda özensiz davrandıkları görülür. Duvar yazılarında "ki" bağlacının yanlış olarak kendisinden önceki kelimeye bitişik yazıldığı örnekler bulunur:

Seda'm iyiki doğdun (EK lb)

Hüzün Kraliçem İyiki Doğdun.

Ben senin neyinimki

\subsubsection{De Bağlact ve De Eki:}

"De" bağlacı ile "-de" ekinin yazılı anlatım çalışmaları sürecinde veya gündelik hayatta sürekli birbirine karıştırıldığı görülür. Bu karışıklıkta bağlaç olan "de", gereksiz yere bitişik, ek olan "-de" ise ayrı yazılmaktadır. Metinlerdeki bu yanlışlığın nedeni, eğitim sürecinde yazım konusunda verilen bilginin öğrenilmesindeki eksiklik ve yetersizliktir.
Duvar yazılarında "de" bağlacının yanlış yazıldığı örnekler çeşitlilik gösterir: Bu örneklerde "de" bağlacının çoğu kez bitişik yazıldığı dikkati çeker. Bazı örneklerde "d" sesinin " $t$ " ye dönüştüğüne rastlanır:

SEN OL DA İSTER YAR OL... İSTER YARA... LÜFUNDA BAŞIMIN ÜSTÜNDE KAHRINDA...

"Seni Seviyorum Pınar yada minik kraliçem...

VarOLda İstersen yar OLMA....!

SevmekteSUÇmu? (Ek 1d)

Elini Vicdanına Koyupta Söyle,/Bu Hayat Nasıl Geçecek Böyle

Sevgilim bağışla affet biraz zor olsada

BİR F16 DEĞİLDİK AMA BİZDE ÇOK ....

SevdikTene oldu

Dövize yüklenin dolar azdıkça bende...

Duvar yazılarında her durumda bitişik yazılması gereken bulunma hali eki “-de"nin ise ayrı yazıldığı iki örnek vardır:

Yanım da kal çok geç rasladım sana

"Kalbim desin Esra Giden Gitsin Sen Kal" (Ek $1 h)$ cümlesinde ise ek olan de kelimeden ayrılmakla kalmamıs, aynı zamanda ekin üzerine gelen bir başka ekle birlikte tuhaf bir görüntü ortaya çıkmıştır.

\subsubsection{Mi Soru Ekinin Yazımı}

Kendisinden önce kelimeden ayrı yazılması gereken "mi" soru ekinin bazı duvar yazılarında bitişik yazıldığı görülmüştür:

\section{Küçükken cennetemibandılar seni \\ GS'mOlurmusun ZEHRA}

Sogudummu Bitti Geçmiş OLSUN (Ek 1c)

\subsubsection{Birleşik Kelimelerin Yazımı}

Birleşik kelimelerin bazıları ayrı, bazıları bitişik yazılır. ${ }^{3} \mathrm{Bu}$, yazım kuralları hususundaki hassas konulardan biridir. Gerek duvar yazılarında gerekse öğrencilerin yazılı anlatım metinlerinde çoğunlukla, birleşik kelimelerden bitişik yazılması gerekenlerin ayrı, ayrı yazılması gerekenlerin ise bitişik yazıldığı görülür. Duvar yazılarında birleşik kelimelerin yazımıyla ilgili hatalı örnekler şunlardır:

O gemi BirgünGelecek

Elbet Birgün

Seni Birgün Değil Bir ömür olsa Sev

Eksik Bir șey ler var

HERȘEYIM

\subsubsection{Kelimelerin Yanlış Yazılması}

Duvar yazılarında tespit ettiğimiz yanlış yazım örnekleri şunlardır: ASLA

BİR Şehri, bi bankı Unutabilirsin Ama bir Kaldırımı

$\mathrm{Az} \underline{\mathrm{Bi}}$ Cesaret 
Duygular Eceliyle ÖLMEZ Vardır BiKatili

SEViYORUMLAN VAR MI Bİ DIYYECEĞİN

Senin Karakterin Benim PisKolijimdenDaha Bozuk

SEN YOKSAN SÜriyELİLER VAR

KAFAMDA ROMANLAR YAZIYORKEN AGZIMDAN BİRKAÇ CÜMLE ANCA ÇIKIYOR...

Çukulata tadında Aşk

Yanım da kal çok geç rasladım sana

Hayat çok açımasız

YÜZÜN ÇİÇİKLERİN EN GÜZELİIIR ( $E k l a)$

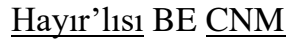

Cemal seni sewiyooom

Seni Seviyorum Pınar yada minik kralicem...

Artık gel yanıma süprizim var

Sende mi? ELİZABED

Kelpeten MIHOOO...!

Hayalperes

\section{$\underline{\text { HAYAL CASH }}$}

Duvar yazılarında tespit ettiğimiz ve yukarıda altını çizerek belirttiğimiz yanlış yazılmış kelimeler, aşağıdaki tabloda doğru yazım şekilleriyle birlikte verilmiştir:

Tablo 1. Duvar Yazılarında Tespit Edilen Yanlış Yazılmış Kelimeler ve Doğru Yazılış Şekilleri

\begin{tabular}{ll}
\hline Duvar Yazılarında & Doğru Yazım \\
\hline Açımasız & Acımasız \\
Bi & Bir \\
Çiçik & Çiçek \\
Gitiği & Gittiği \\
Birgün & Bir gün \\
Süpriz & Sürpriz \\
Anca & Ancak \\
Çukulata & Çikolata \\
Herşeyim & Her şeyim \\
Yawşak & Yavşak \\
PisKolijimden & Psikolojimden \\
Süriyeli & Suriyeli \\
Birşeyler & Bir şeyler \\
Kelpeten & Kerpeten \\
Hayalperes & Hayalperest \\
Hayal cash & Hayalkeş \\
Rasladım & Rastladım \\
Hayır'lısı & Hayırlısı \\
Bitanem & Bir tanem \\
Elizabed & Elizabeth \\
Kralicem & Kraliçem \\
\hline
\end{tabular}

3.1.6. Fiil Çekiminin Yanlış Yapılması

\section{SIZZ BOYAYIN BİZ YİNE CIIZDIM}

\section{GÜYA SON AŞKIN OLUÇAKTIM.}

SILMeyIN Tekrar YAZACAZ

Şimdi gidicenya.. Cehennemin dibine git...!

Duvar yazılarındaki fiil çekimlerinin yanlışlığı, çoğunlukla yazılara hâkim olan konuşma dilinden kaynaklanır.
Konuşma dili, yazı diline göre kolaylığı tercih eder. Bu yüzden duvar yazısı yazarı da çoğu kez, yazı dilinin kuralcı yapısından kaçar ve konuşma dilinin esnekliğine ve rahatlığına yaslanarak duygu ve düşüncelerini aktarır.

\subsubsection{Diğer}

"Hatalar ve yanlıșlar iyi bir öğretmendir" şeklindeki duvar yazısı örneğinde görüldüğü üzere aynı anlama gelen sözcüklerin kullanımından kaynaklanan bir anlatım bozukluğu vardır. "AȘKI TARİFET BANA" şeklinde karşımıza çıkan duvar yazısında ise birleşik fiilin yazımında yanlışlık yapılmıştır.

Aşağıdaki cümlelerde düzeltme işaretinin kullanılmayışından kaynaklanan bir yazım bozukluğu dikkati çekmektedir:

VarOLda İstersen yar OLMA...! (Ek lf)

SEN OL DA İSTER YAR OL... İSTER YARA... LÜFUNDA BAŞIMIN ÜSTÜNDE KAHRINDA... (Ek $1 g$ )

AnLASaydı beni sever idi CANdanAhdım var benim o 'NAZLI' YARDAN!

"BENIM İLK K/ANATLARIMI BABAM KIRDI" şeklindeki duvar yazısında ise satır sonuna gelen kelimenin yanlış bölünmesine dayalı bir yazım hatası söz konusudur. Yazıda "kanat" kelimesindeki K harfi yukarı satırda kalmış, diğer harfler ise alt satıra yazılmıştır. Ancak bu yazım hatasının bilinçli bir şekilde, söylem gücünü artırmak maksadıyla yapıldığı düşünülmektedir.

\section{Sonuç ve Değerlendirme}

Duvar yazılarındaki yazım hatalarının sebepleri çeşitlidir: Bunları şu şekilde sıralayabiliriz:

(i) Yazımların gizlice ve aceleyle yapılmış olması

(ii) Yazım kuralları konusundaki bilgi eksikliği

(iii) Yazılarda konuşma dilinin hâkim olması

(iv) Söylem gücünü arttırma

Okuldaki yazma eğitimi sürecinde de yanlış yazılan bir kelimenin neden yanlış yazıldığı öğrenciye sorulduğunda öğrencinin verdiği en klasik cevap aceleyle yazdım, şeklindedir. Bu cevabın haklılık payı olabilir. Ancak çoğu kez öğrencilerin yazımı hakkında bilgi sahibi olmadıkları kelimeleri de aceleyle yazdıklarını beyan ederek bu kılıf altına gizlendikleri görülmektedir.

Duvar yazılarındaki metinler arasında yazım ve noktalama konusunda kusursuz olanlar da vardır. Bunlar, hem yazıya hem de içeriğe dikkat eden yazarların kaleminden çıkmış metinlerdir. Yazım kuralları öğretilirken yanlış yazım örnekleriyle birlikte bu tür metinler de öğrencilere gösterilebilir.

Yazma eğitimi süreci, zorluklarıyla birlikte dikkate alındığında birçok bileşenin birlikteliği dikkati çeker: okuma, gözlem, düşünme, sentez yapma. Yazma, bıkmadan usanmadan gözden geçirerek yeniden yazma. Bütün bunlar arasında yazılan metnin biçimsel kalitesini etkileyen en önemli husus, yazım ve noktalamadır. Yazım ve noktalama, yazma eğitiminden bağımsız bir konu olarak değil, onun içindeki bir bileşen olarak ele alınmalıdır. 
Temizkan ve Ünlüoğlu (2017), çalışmalarında, görsellerle desteklenen yazılı anlatım etkinliklerin öğrencilerin yazılı anlatım becerilerinin dil ve anlatım boyutunu geliştirmede etkili olduğu sonucuna varmışlardır. Fındık Dönmez (2013)çalışmasında, Türkçe dersinde karikatür kullanılarak hedeflenen kazanımlara ulaşmada deneysel gruptaki öğrencilerin kontrol grubundaki öğrencilere oranla okuduğunu anlama ve yazma beceri alanlarında daha başarılı oldukları vurgulanmıștır. Görseller ve çoklu ortam araçlarının yoğun olarak kullanıldığı sınıflarla günümüz öğrencisinin dünyasına yaklaşılmaktadır. $\mathrm{Bu}$ yaklaşımla birlikte öğrenciye güncel hayatı sunan bir eğitim ortamı olușturulmuş olur. Bu durum hem öğrenciler için hem de eğitimciler için firsatlar sunmaktadır (Kurudayığlu ve Tüzel, 2010). Bu durum alanda yapılan benzer çalışmalarda da görülmektedir. Nitekim Yıldız (2009) çalışmasında görsel ve işitsel araçların öğrencilerin okuma ve yazma becerisi üzerinde etkili olduğu sonucuna varmıştır. Çünkü görsel araçlar Türkçe eğitimini destekleyen önemli unsurların başında gelir. Görsel unsurlar konunun kolay anlaşılmasını sağlar (Özsoy, 2007). Milli Eğitim Bakanlığı Türkçe dersi öğretim programında (MEB, 2006: 56-57) ders kitaplarındaki okuma metinlerinin fotoğraf, resim, afiş, grafik, karikatür, çizgi film kahramanları, atasözü, özdeyiş, duvar yazısı ve sloganlarla desteklenebileceğine vurgu yapılmıştır. Görseller (karikatür, fotoğraf, video vb.) ilgi çekici materyallerdir. Yazım kurallarına yönelik uygulamalar, öğrencilerin dikkatini çekecek metinlerle yapıldığı takdirde, öğrenme süreci daha hızlı ve etkili olacaktır.

Sarıkaya (2017), çalışmasında görsel okuma eğitiminin veya becerisinin kazandırılmasında tüm bireylere (öğretmenler, aileler vb.) önemli görevler düştüğüne ve görsel okuma becerisinin öğrencilerin daha fazla üst düzey düşünme becerileri edinmeleri için önemli olduğu hususuna dikkat çeker. Devamında öğrencilere bazen bazı konuların çok karmaşık geldiğini ve materyal kullanımıyla bu konuların karmaşık olmaktan çıkarıldığını; anlamaları kolaylaşmış ve yaşları gereği soyut kavramları anlamakta zorlanan öğrencilerin materyaller sayesinde soyut kavramları daha rahat öğrenme firsatı yakalamış olduğunu Yalın'dan (2010) aktarır.

Duvar yazıları fotoğraflandığı takdirde bir tür görsel materyale dönüşür. Akıllı tahta veya projeksiyon aracılı̆̆ıyla gösterilecek renkli görsel bir materyal, sadece yazıdan ibaret bir metne göre çok daha ilgi çekici olacak; böylece duvar yazıları eğitim-öğretim malzemesine dönüşecektir. Birçoğu gençler tarafından yazılan duvar yazıları, yazma eğitimi etkinliklerinde kullanıldığı takdirde öğrenci, kendi yaşıtlarından birinin yazdığı bir duvar yazısı metnini merak ve heyecanla okuyacak, içeriğinde kendisinden bir parça bulacak ve derse karşı ilgisi de böylece artacaktır. Yapılan çalışmalara bakıldığında yaratıcı yazma vb. etkinliklerin öğrencilerin serbest yazma becerilerini ve yazılı anlatıma yönelik tutumlarını olumlu etkilediğine dikkat çekilmiștir (Öztürk, 2007; Beydemir, 2010; Ak, 2011; Akkaya, 2011).

Duvar yazıları kısa, etkili ve vurgulu metinlerdir. Yazım ve noktalama hususunda çoğu kez kuralsızlığın hâkim olduğu bu yazılarla öğrencinin dikkatini çekmek, herhangi başka bir metne nazaran daha kolaydır. Bu sebeple bu tarz metinlerin gerek öğrenciler gerekse öğretmenlerce tespit edilip fotoğraflanmasının ve yazma etkinliği çalışmalarının çeşitli aşamalarında kullanılmasının yazma eğitimi sürecinde olumlu etkiler yaratacağı düşünülmektedir.

Çalışmadan hareketle konu ile ilgili şu önerilerde bulunulabilir:

(i) Duvar yazılarının sadece dilbilgisi açısından değil metin olarak da incelenmesi yapılmalı ve gerekirse kelime serveti ortaya çıkarılmaya çalışılmalıdır.

(ii) Duvar yazıları ile sosyal medya yazıları karşılaştırılarak bu iki unsurun birbirini etkileme durumu incelenmelidir.

(iii) Duvar yazılarının konu bakımından incelenmesi yapılarak güncel hayatla uyumluluğu tespit edilmeye çalışılmalıdır.

(iv) Literatürde olmayıp da duvar yazılarında kullanılan sözcükler tespit edilerek bu sözcüklerin kaynağı ile ilgili çalışmalar yapılabilir.

(v) Tüm bunlardan hareketle duvar yazılarının Türkçe eğitiminde kullanılabilirliği ile ilgili çalışmalar yapılmalı ve temel dil becerilerinin öğretiminde eğitim ortamına aktarımı sağlanmalıdır.

\section{Notlar}

${ }^{1}$ İki kez Pulitzer ödülü alan Mailer, ilk kitab1 "The Naked and the Dead" ile dünya çapında büyük başarı kazandı. İkinci Dünya Savaşı'yla ilgili olarak yazılmış en iyi romanlardan biri olarak kabul edilen roman, Mailer'i 1948 yılında daha 25 yaşındayken şöhrete kavuşturmuştur (Kimkimdir, 2017).

2 Balyemez (2017), "Eğer ki ve İllaki Kelimelerinin Yazımı Hakkında" adlı makalesinde içerisinde "ki" bağlacının yer aldığı "eğer ki" ve illaki kelimelerinin yazımıyla ilgili bilgi kirliliğinden, nedenlerinden ve bu tarz bilgi yanlışlı̆̆ını önleyebilecek çalışmalardan bahsetmiştir.

3 "Biraz, birazı, birkaç, birkaçı, birtakım, birçok, birçoğu, hiçbir, hiçbiri, herhangi belirsizlik sıfat ve zamirleri, gelenekselleşmiş olarak bitişik yazılır” (Korkmaz vd., 2001: 248).

${ }^{4}$ TDK sözlüğünde hayalkeş kelimesine rastlanamamıştır. Duvar yazısı yazarı "esrarkeş" kelimesine özenerek "hayal cash" şeklinde bir tamlama tasarlamış olmalıdır. Hayalkeş kelimesi, Hayalperest ve hayalperver kelimelerinin eş veya yakın anlamlısı olarak "Hayal kurmayı alışkanlık durumuna getiren kimse, hayalci" anlamlarında kullanılabilir. İngilizce cash kelimesi "para" anlamına gelir, ancak duvar yazısı yazarı bu sözcüğün anlamından değil okunuşundan yararlanarak okunuşu "keş" şeklinde olan kelimenin ses gücünden yararlanmış olmalıdır.

\section{Kaynakça}

Ak, E. (2011). Yaratıcı Yazma Tekniklerinin Ilköğretim 5. Sinıf Öğrencilerinin Türkçe Dersindeki Yazılı Anlatım Becerileri Üzerindeki Etkisi. Yüksek Lisans Tezi. İzmir: Dokuz Eylül Üniversitesi.

Akkaya, N. (2011). İlköğretim 6. Sınıf Türkçe Dersinde Yaratıcı Yazma Yaklaşımının Türkçe Dersine Yönelik Tutumuna Etkisi. Buca Eğitim Fakültesi Dergisi, 30, 311-319.

Bağcı, H. (2011). İlköğretim 8. Sinıf Öğrencilerinin Noktalama İşaretleri ile Yazım Kurallarını 
Uygulayabilme Düzeyi. Turkish Studies - International Periodical For The Languages, Literature and History of Turkish or Turkic 6(1), 693-706.

Balyemez, S. (2017). Eğer ki ve İllaki Kelimelerinin Yazımı Hakkında. Littera Turca Journal of Turkish Language and Literature, 3(2), 55-68.

Beydemir, A. (2010). Illkögretim 5. Sinıf Türkçe Dersinde Yaratıcı Yazma Yaklaşımının Yazmaya Yönelik Tutumlara, Yaratıcı Yazma ve Yazma Erişisine Etkisi. Yüksek Lisans Tezi. Denizli: Pamukkale Üniversitesi.

Carter, J. (2002). CreatingWriters A Creative Writing Manual For Schools. New York: Routledge.

Coşkun, E. (2007). Türkçe Öğretimi. İçinde: Ahmet Kırkkılıç, Hayati Akyol (Ed.), Yazma Becerisi içinde (sayfa: 49-91). Ankara: Pegem Akademi Yayınları.

Demir, A. T. (2014). Türk Dili ve Edebiyatı Öğretimi. İçinde: M. D. Erdem, A. Akkaya (Ed.), Türk Dili ve Edebiyatı Öğretimi Temel Kavram ve Terimleri (s. 1-56). Ankara: Pegem Akademi Yayınları.

Findık Dönmez, A. (2013). İlköğretim 7. Sinıf Öğrencilerinin Türkçe Öğretiminde Okuduğunu Anlama ve Yazma Becerilerinin Gelişmesinde Karikatürün Etkisi. Yüksek Lisans Tezi. Bolu: Abant İzzet Baysal Üniversitesi.

Kellogg, R. T. (2008). Training writing skills: A cognitive developmentalperspective. Journal of writing research, $1(1), 1-26$.

Kimkimdir (2017). Norman Mailer (1923 - 2007). (Erişim: 10.12.2017), http://www.kimkimdir.gen.tr/kimkimdir. php?id=3972

Korkmaz, Z., Zülfikar, H., Akalın, M., Ercilasun, A.B., Parlatır, İ., Gülensoy, T., \& Birinci, N. (2001). Türk Dili ve Kompozisyon Bilgileri. Ankara. Yarg1 Yayınevi.

Kurudayığlu. M., \& Tüzel, M. S. (2010). 21. Yüzyıl Okuryazarlık Türleri, Değişen Metin Algısı ve Türkçe Eğitimi. TÜBAR, 28, 283-298.

MEB (2006). Türkçe Dersi Öğretim Programı ve Kılavuzu. Ankara: Devlet Kitapları Basımevi.

Özbay, M. (2013a). Özel Öğretim Yöntemleri 1. Ankara: Öncü Kitap.

Özbay, M. (2013b). Yazma Eğitimi. İçinde: M. Özbay (Ed.) Yazma Eğitiminde Noktalama ve İmla, (s. 181-196). Ankara Pegem Akademi Yayınları.

Özsoy, V. (2007). Görsel Sanatlar Eğitimi, Resim-İş Eğitimi Tarihsel ve Düşünsel Temelleri. Ankara: Gündüz Eğitim ve Yayıncılık.

Öztürk, E. (2007). Illköğretim Beşinci Sinıf Öğrencilerinin Yaratıcı Yazma Becerilerinin Değerlendirilmesi. Doktora Tezi. Ankara: Gazi Üniversitesi.

Raimes A. (1983). Techniques in Teaching Writing. New York: Oxford University Press.

Sarıkaya, B. (2017). Türkçe Öğretiminde Görsel Okuma. Anemon Muş Alparslan Üniversitesi Sosyal Bilimler Dergisi, 5(3),779-796.
Sezer, A., \& Erdost, Ö. (2011). Dil ve Anlatım Sanatlart. Ankara: Pulat Basımevi.

Temizkan M., \& Ünlüoğlu, C. (2017). Görsel Destekli Yazma Etkinliklerinin Öğrencilerin Yazma Başarılarına ve Yazmaya Yöne lik Görüşlerine Etkisi. Ziya Gökalp Eğitim Fakültesi Dergisi, 30, 437-448.

Uludağ, E. (2002). İlköğretim İkinci Kademe Öğrencilerinin Yazım ve Noktalama Kurallarını Uygulama Beceri Düzeyleri. Erzincan Eğitim Fakültesi Dergisi 4(1), $97-$ 114.

Yalın, H. İ. (2010). Öğretim Teknolojileri ve Materyal Geliştirme. Ankara: Pegem Akademi Yayınları.

Yazım Kılavuzu (2012). Ankara: Türk Dil Kurumu Yayınlar1.

Yıldırım A. ve Şimşek H. (2011). Sosyal Bilimlerde Nitel Araştırma Yöntemleri. Ankara: Seçkin Yayınları.

Yıldız, S. (2009). Ilkokuma Yazma Öğretiminde Çoklu Ortam Uygulamalarının Etkililiği. Doktora Tezi. Bolu: Abant İzzet Baysal Üniversitesi.

\section{Ekler:}

Ek 1. Duvar Yazısı Örnekleri

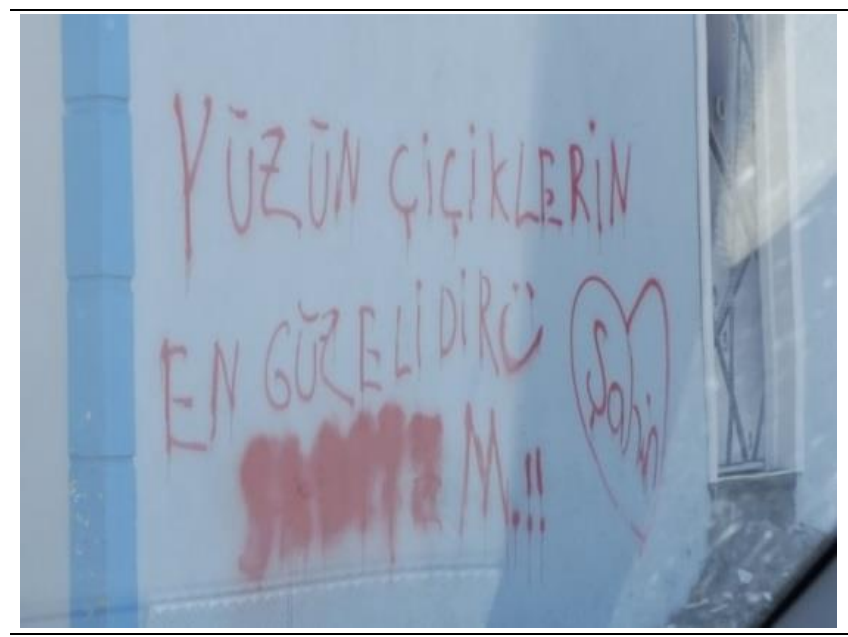

(a)

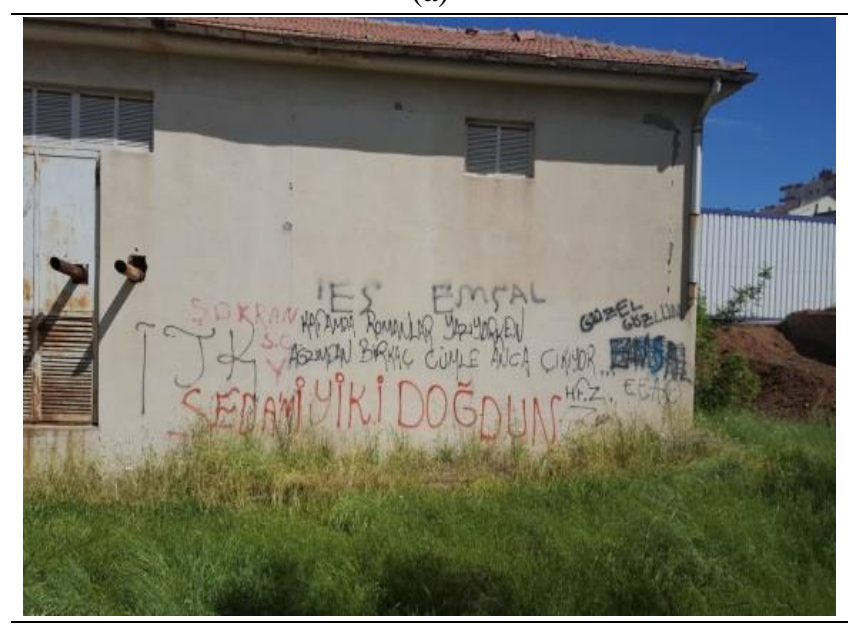

(b) 


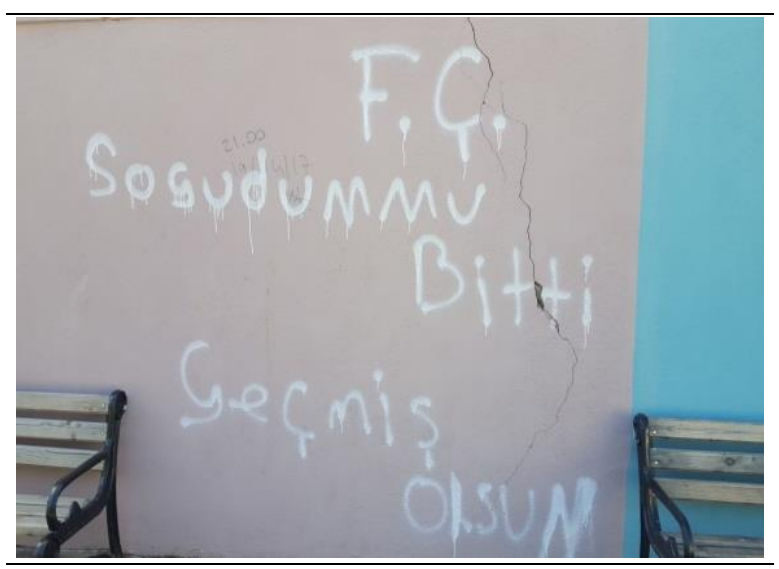

(c)

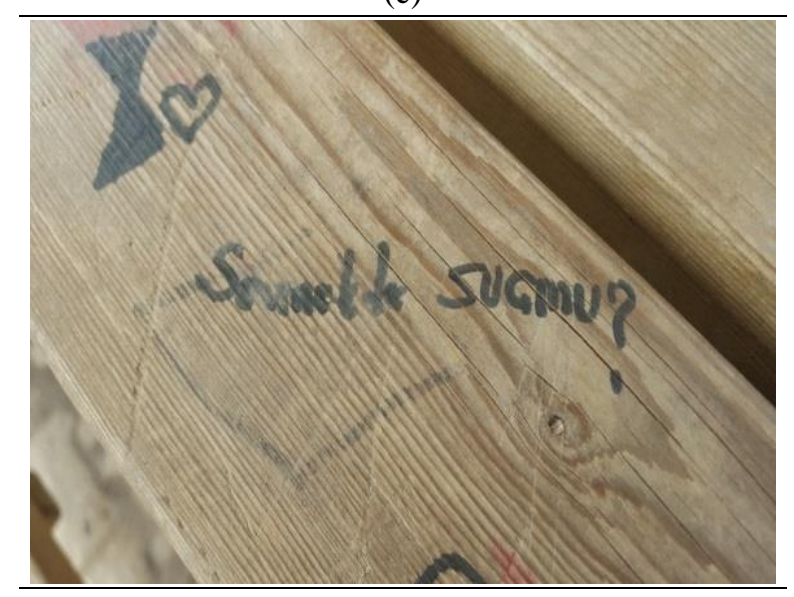

(d)

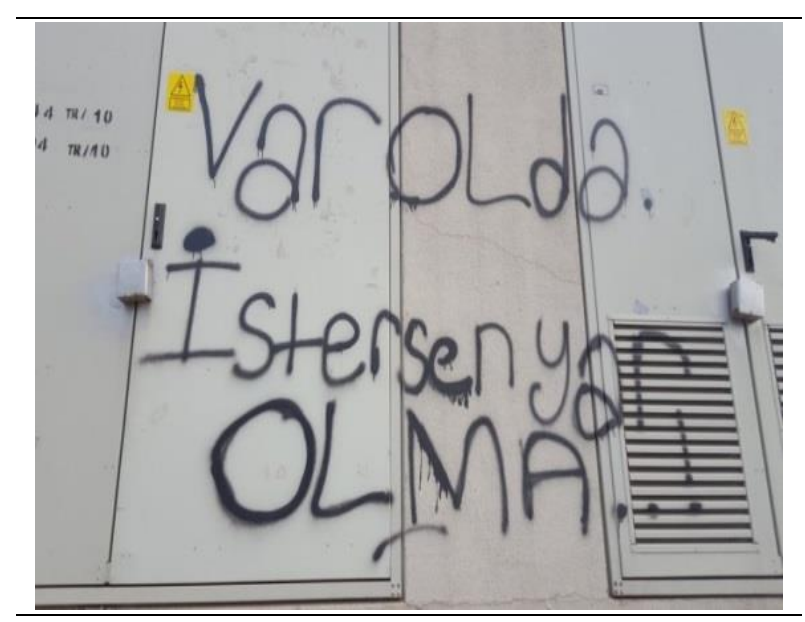

(e)

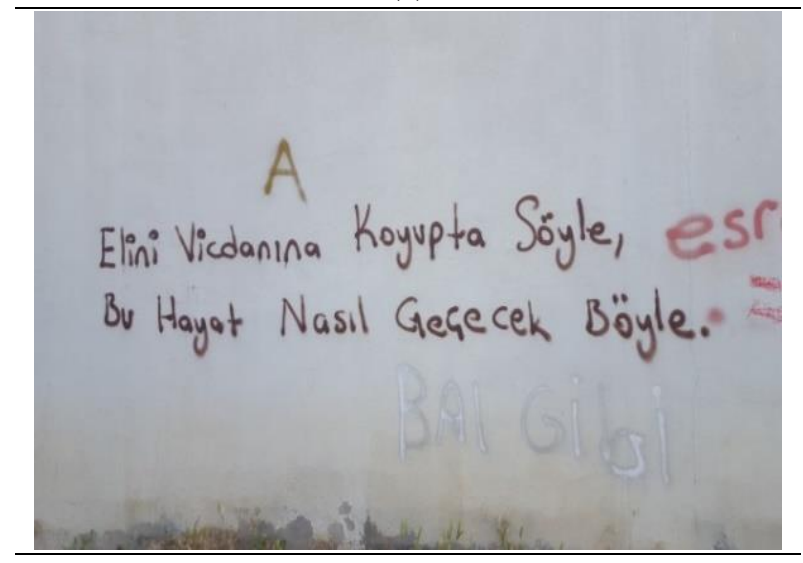

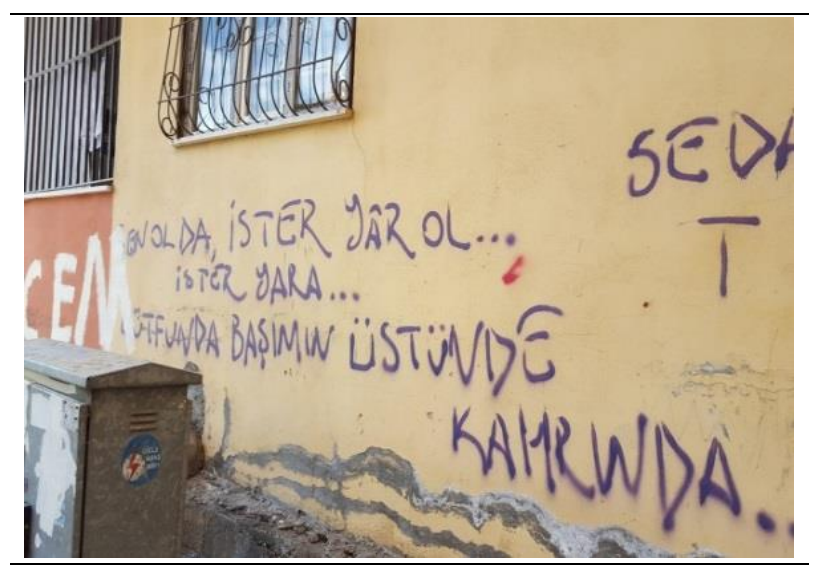

(g)

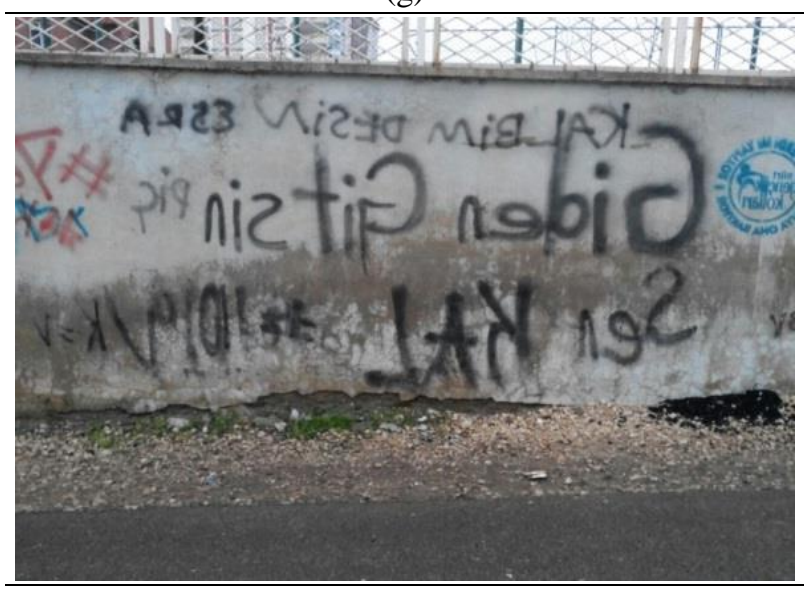

(h) 